\title{
Glaciochemical investigation of an ice core from Belukha glacier, Siberian Altai
}

\author{
Susanne Olivier, ${ }^{1,2}$ Margit Schwikowski, ${ }^{2}$ Sabina Brütsch, ${ }^{2}$ Stella Eyrikh, ${ }^{4}$ \\ Heinz W. Gäggeler, ${ }^{1,2}$ Martin Lüthi, ${ }^{3}$ Tatyana Papina, ${ }^{4}$ Matthias Saurer, ${ }^{2}$ \\ Ulrich Schotterer, ${ }^{1}$ Leonhard Tobler, ${ }^{2}$ and Edith Vogel ${ }^{1}$ \\ Received 31 July 2003; revised 29 August 2003; accepted 10 September 2003; published 15 October 2003.
}

[1] During summer 2001, a $140 \mathrm{~m}$ long ice core was recovered from the Belukha glacier $\left(49^{\circ} 48^{\prime} 26^{\prime \prime} \mathrm{N}\right.$, $86^{\circ} 34^{\prime} 43^{\prime \prime} \mathrm{E}, 4062 \mathrm{~m}$ a.s.l.) in the Siberian Altai. The englacial temperature of $-17^{\circ} \mathrm{C}$ indicates that this unique glaciochemical record is well preserved and suitable for the reconstruction of air pollution levels in this previously unexplored region. The upper $86 \mathrm{~m}$ were dated by ${ }^{210} \mathrm{~Pb}$ and cover the period 1862-2001. A lack of strong winter minima was observed in the $\delta^{18} \mathrm{O}$ record and attributed to the small amount of precipitation during that season and to wind erosion. The ion concentrations are comparable to those observed in Swiss glaciers, except for ammonium and formate, where enhanced concentrations indicate biogenic emissions from Siberian forests. Sulfate, ammonium and nitrate records all show anthropogenic impacts despite the remoteness of this site. INDEX TERMS: 1827 Hydrology: Glaciology (1863); 3344 Meteorology and Atmospheric Dynamics: Paleoclimatology; 1610 Global Change: Atmosphere (0315, 0325). Citation: Olivier, S., M. Schwikowski, S. Brütsch, S. Eyrikh, H. W. Gäggeler, M. Lüthi, T. Papina, M. Saurer, U. Schotterer, L. Tobler, and E. Vogel, Glaciochemical investigation of an ice core from Belukha glacier, Siberian Altai, Geophys. Res. Lett., 30(19), 2019, doi:10.1029/ 2003GL018290, 2003.

\section{Introduction}

[2] Pollution from human activities has affected most of the atmospheric environment. High elevated cold glaciers situated in mid-latitude regions are well suited for reconstructing atmospheric concentrations of trace species and to document the impact of humans on the environment. Ice core records from mid-lattitude alpine glaciers have provided unique insights into past atmospheric pollution [e.g. Wagenbach, 1989]. For example enhanced acidity, sulfate and nitrate concentrations were observed in the twentieth century and attributed to $\mathrm{SO}_{2}$ and $\mathrm{NO}_{\mathrm{x}}$ emissions from fossil fuel consumption [e.g. Schwikowski et al., 1999a, 1999b; Preunkert et al., 2001]. Increases in agricultural activity and biomass burning produced elevated concentrations of ammonium during this time period [e.g. Döscher et al., 1996;

\footnotetext{
${ }^{1}$ Department of Chemistry and Biochemistry, University of Bern, Bern, Switzerland.

${ }^{2}$ Paul Scherrer Institute, Villigen, Switzerland.

${ }^{3}$ Versuchsanstalt für Wasserbau, Hydrologie und Glaziologie, ETH Zürich, Zürich, Switzerland.

${ }^{4}$ Institute for Water and Environmental Problems, Siberian Branch of the Russian Academy of Sciences, Barnaul, Russia.
}

Copyright 2003 by the American Geophysical Union. 0094-8276/03/2003GL018290
Kreutz et al., 2001; Shugui et al., 2003]. Anthropogenic emissions also caused significant concentration changes of carbonaceous particles [Lavanchy et al., 1999] and heavy metals [e.g. Van de Velde et al., 2000; Rosman et al., 2000].

[3] Here we present an ice core record from the Altai mountain region. This area is located close to major sources of air pollution in East Kazakstan and South Siberia as well as the nuclear test site of Semipalatinsk (Figure 1). It is therefore assumed to be affected by emissions of $\mathrm{SO}_{2}$, heavy metals, and nuclear fallout. In addition, the Altai region is interesting for climate research, since it is highly continental with pronounced seasonality.

[4] In order to reconstruct air pollution levels in this very remote region, a deep ice core was drilled on the Belukha glacier $\left(49^{\circ} 48^{\prime} 26.3^{\prime \prime} \mathrm{N}, 86^{\circ} 34^{\prime} 42.8^{\prime \prime} \mathrm{E}, 4062 \mathrm{~m}\right.$ a.s.1.) in July 2001. This glacier is located on a saddle between the two summits of Belukha, the highest mountain in the Altai (4506 $\mathrm{m}$ a.s.1.), and is probably the only site suitable for paleo studies in this region.

\section{Methods}

\subsection{Ice Core Drilling and Glaciological Survey}

[5] Drilling of the $140 \mathrm{~m}$ long ice core was performed with the lightweight electromechanical device FELICS [Ginot et al., 2002]. The drilling site was carefully chosen based on the results of an exploratory study conducted in 2000 and on ice thickness measurements. It is located at the western margin of the glacier and is characterized by an unambiguous ice flow direction.

[6] During the two-week drilling campaign a glaciological survey of surface and bedrock topography was conducted. The surface topography was measured with a Garmin GPS system. Ice thickness was determined in the main part of the glacier, with special emphasis on the western side where ice core drilling took place. A lightweight radio echo system with a center frequency of $100 \mathrm{MHz}$ was used. Calibrated NTC thermistors were employed to measure englacial ice temperatures in the borehole.

[7] For the duration of the drilling campaign, an automatic weather station (AWS) was installed on the glacier to measure air temperature, wind speed, wind direction and humidity every $30 \mathrm{~min}$.

[8] Ice core sections up to $0.7 \mathrm{~m}$ long and with a diameter of $7.8 \mathrm{~cm}$ were recovered and sealed in polyethylene tubes in the field and transported frozen to Switzerland.

\subsection{Chemical and Stable Isotope Analyses}

[9] Samples from the ice core sections were prepared in a $-20^{\circ} \mathrm{C}$ cold room at the Paul Scherrer Institute. Prior to 


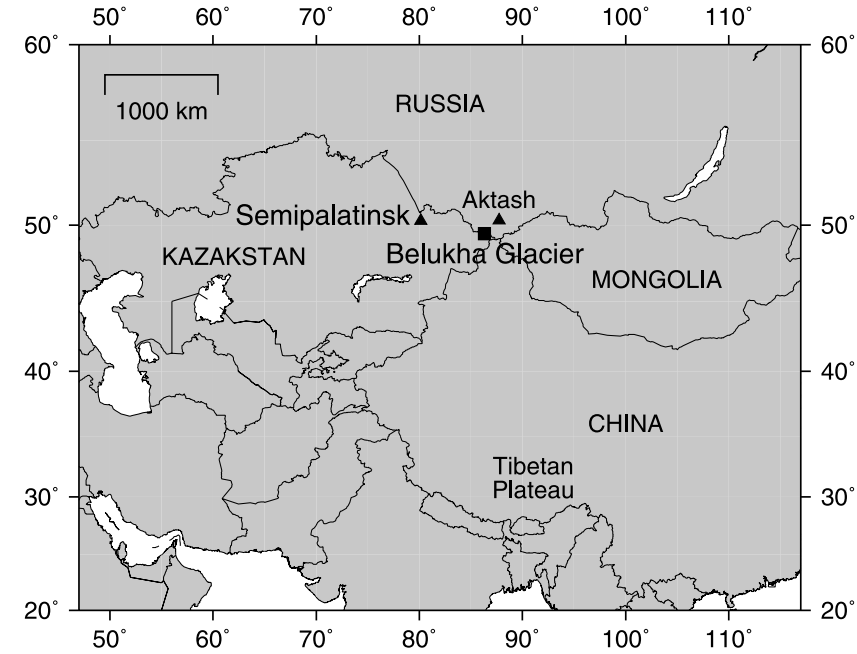

Figure 1. Map showing the location of the Belukha glacier (square) in the Altai mountain region, along with the nuclear test site in Semipalatinsk and the mercury mine in Aktash.

sampling, visual stratigraphy was recorded and density measurements done. Outer parts of the ice core were used for tritium (depth resolution of $0.70 \mathrm{~m}$ for $0-35 \mathrm{~m}$, [Schotterer et al., 1998]) and ${ }^{210} \mathrm{~Pb}$ analyses (depth resolution of $1.40 \mathrm{~m}$ for $0-86 \mathrm{~m}$, [Gäggeler et al., 1983]). Inner ice core sections were sampled with $5 \mathrm{~cm}$ resolution for water-soluble species (sodium, ammonium, potassium, magnesium, calcium, fluoride, acetate, formate, chloride, nitrate, sulfate and oxalate) and $\delta^{18} \mathrm{O}$, and were analyzed down to $41 \mathrm{~m}$ using established techniques.

\section{Results and Discussion}

\subsection{Glacier Characteristics}

[10] Measured ice thicknesses ranged from $180 \mathrm{~m}$ at the saddle to about $40 \mathrm{~m}$ near the summit slopes and were $140 \mathrm{~m}$ around the drilling site. Most of the ice in the core was deposited along a $150 \mathrm{~m}$ upstream flowline starting at the bergschrund. The elevation difference is roughly $50 \mathrm{~m}$ so that a significant change in precipitation amount and composition is unlikely.

[11] The englacial temperature was constant at $-17.25 \pm$ $0.07^{\circ} \mathrm{C}$ between 25 and $75 \mathrm{~m}$ depth from readings of 7 different sensors. Model calculations of a similar highaltitude glacier showed that such an unusual temperature profile may be caused by heat fluxes towards steep rock faces, such as the partially snow covered north face of Belukha [Lüthi and Funk, 2001]. This part of the glacier belongs to the cold infiltration recristallization zone [Shumskii, 1964].

[12] Meltwater-infiltration ice lenses up to $20 \mathrm{~cm}$ thick were observed in the ice core, suggesting that surface melting and subsequent refreezing might have occurred during warm summer periods. Average temperatures from the AWS were $-4 \pm 3^{\circ} \mathrm{C}(1 \sigma)$ during the day and $-5 \pm 3^{\circ} \mathrm{C}$ during the night (max: $2^{\circ} \mathrm{C}$, min: $-11^{\circ} \mathrm{C}$ ), indicating occasional surface melting. The percentage of melt in the upper $30 \mathrm{~m}$ results as $17 \%$ after correction for firn densification [Tarussov, 1992].

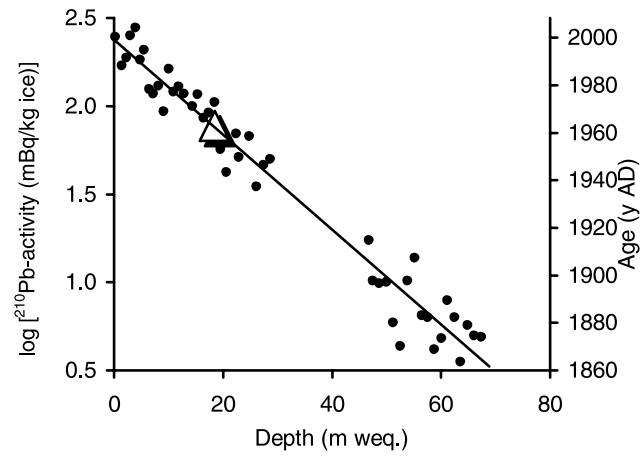

Figure 2. Logarithm of the ${ }^{210} \mathrm{~Pb}$ activity versus depth of the ice core together with a linear trend line and the calculated age (righthand scale). The triangle marks the tritium reference horizon.

\subsection{Nuclear Dating}

[13] The tritium record shows a maximum at a depth of $18 \mathrm{~m}$ water equivalent (weq.) which is due to the maximum fallout from nuclear weapons testing in 1963 [Schotterer et al., 1998].

[14] The record of ${ }^{210} \mathrm{~Pb}$ activity is shown in Figure 2 together with the calculated age [Gäggeler et al., 1983] and the tritium horizon. The age at $69 \mathrm{~m}$ weq. is $1862 \pm 5 \mathrm{AD}$ (expanded uncertainty with $95 \%$ level of confidence [ISO, 1995]) and thus the mean annual net accumulation is $0.50 \mathrm{~m}$ weq.

[15] The two nuclear dating methods are in excellent agreement. In addition, the linearity of the decrease of the ${ }^{210} \mathrm{~Pb}$ activity with depth $\left(\mathrm{r}^{2}=0.95\right)$ implies that the glaciochemical record is preserved and is not significantly altered by melting processes.

\subsection{Oxygen Isotopic Composition}

[16] The $\delta^{18} \mathrm{O}$ record is presented in Figure 3 and shows a relatively high average value of $-12 \%$ for this evelation (4062 $\mathrm{m}$ a.s.1.). At the nearby meteorological station Ak-kem (2000 m a.s.l., 7 km north of Belukha) precipitation during the summer months (June-August) dominates (58\%) while winter precipitation (December-February) accounts only for $4 \%$. This may partially explain the high average $\delta^{18} \mathrm{O}$ value observed in the core and the absence of strong winter minima in the $\delta^{18} \mathrm{O}$ record. In addition, at Ak-kem the mean annual precipitation (1991-2000) is $0.53 \mathrm{~m}$. Generally, the amount of precipitation is expected to increase with altitude, which is not the case at Belukha $(0.50 \mathrm{~m}$ weq./year). This indicates that some portion of the fresh snow at this exposed saddle site may be wind eroded.

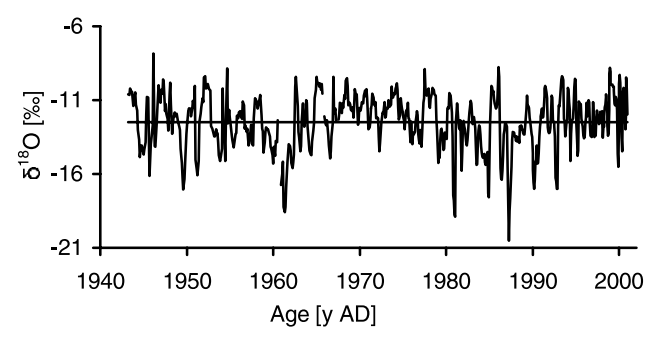

Figure 3. Variation of $\delta^{18} \mathrm{O}$ in the ice core. The mean value $-12 \%$ is shown as a solid line. 
The average wind speed during the drilling campaign was $5.0 \mathrm{~m} / \mathrm{s}$ and a maximum of $28.1 \mathrm{~m} / \mathrm{s}(30 \mathrm{~s}$ average) was recorded. Due to a lack of reliable winter precipitation the identification of annual layers (using $\delta^{18} \mathrm{O}$ and the occurence of ice lenses) is not always unambiguous. Nevertheless, the variations in $\delta^{18} \mathrm{O}$ are related to annual fluctuations.

\subsection{Water-Soluble Ionic Species}

[17] Table 1 shows median concentrations of the major water-soluble ions. In the Altai the primary anion and cation components are sulfate $(50 \%)$, formate $(23 \%)$, nitrate $(21 \%)$, ammonium $(57 \%)$ and calcium $(32 \%)$.

[18] Good correlations $\left(\mathrm{r}^{2}>0.55 ; \mathrm{n}=662 ; \mathrm{r}^{2}\right.$ from log. values) are observed between the ions ammonium, nitrate and sulfate as well as calcium, magnesium and sodium. Ammonium, nitrate and sulfate are related to anthropogenic emissions, whereas calcium, magnesium and sodium are originating from dust (from the arid and semi-arid regions of central Asia and even northern Africa [Liu et al., 1981; Parrington et al., 1983; Gao et al., 1992]).

[19] Concentration levels in the Alps and in the Altai are comparable, except for formate and ammonium, where enhanced concentrations in the Altai suggest that there is an additional source from the Siberian forests.

[20] In ice cores, sodium and chloride are often attributed to a sea-salt origin, resulting in $\mathrm{Cl}^{-} / \mathrm{Na}^{+}$ratios close to 1.16 [Keene et al., 1986]. The significantly different average ratio at Belukha glacier (median $\mathrm{Cl}^{-} / \mathrm{Na}^{+}$of 1.0) as well as its strong fluctuation $(\sigma=0.8)$ are likely caused by the high continentality of the area. Any long-range transport of coarse-mode sea-salt aerosol is highly unlikely, as it is also the case in Tien Shan, northwest China [Kreutz et al., 2001]. Wake et al. [1993] reported that sodium and chloride signals in the northeastern regions of the Tibetan Plateau could relate to monsoon precipitation but are effectively masked by sodium and chloride derived from the arid and semi-arid regions in China. Sodium in Belukha glacier could additionally originate from evaporite deposits (halite) in the arid regions of the northern and western Tibetan Plateau [Shugui et al., 2003; Kreutz et al., 2001] and chloride from coal combustion.

[21] In order to extract trends from the concentration records, annual averages were calculated based on the ${ }^{210} \mathrm{~Pb}$-dating (Figure 4). For calcium (also representative for magnesium), formate (representative for oxalate) and

Table 1. Median Concentrations of Major Ions [ $\mu$ eq./L] in Ice from Altai, the Swiss Alps and the Tien Shan

\begin{tabular}{lccc}
\hline \multicolumn{1}{c}{ Site } & $\begin{array}{c}\text { Altai, Belukha } \\
\text { glacier } \\
\text { (This work) }\end{array}$ & $\begin{array}{c}\text { Swiss Alps, } \\
\text { Grenzgletscher } \\
\text { [Eichler, 2000] } \\
\text { 1945-1983 }\end{array}$ & $\begin{array}{c}\text { Tien Shan, } \\
\text { Inilchek glacier } \\
\text { [Kreutz et al., 2001] } \\
1992-1998\end{array}$ \\
Period of record & $1940-2000$ & 4200 & 5100 \\
Elevation [m a.s.1.] & 4062 & 1.0 & 10.9 \\
Sodium & 1.0 & 5.7 & 9.7 \\
Ammonium & 11.4 & 0.3 & 0.9 \\
Potassium & 0.4 & 1.2 & 4.7 \\
Magnesium & 1.6 & 9.1 & 66.2 \\
Calcium & 9.4 & 1.3 & - \\
Formate & 4.6 & 1.2 & 9.7 \\
Chloride & 0.9 & 3.3 & 5.5 \\
Nitrate & 4.3 & 11.1 & 13.5 \\
Sulfate & 11.0 & 0.2 & - \\
Oxalate & 0.4 & & \\
\hline
\end{tabular}

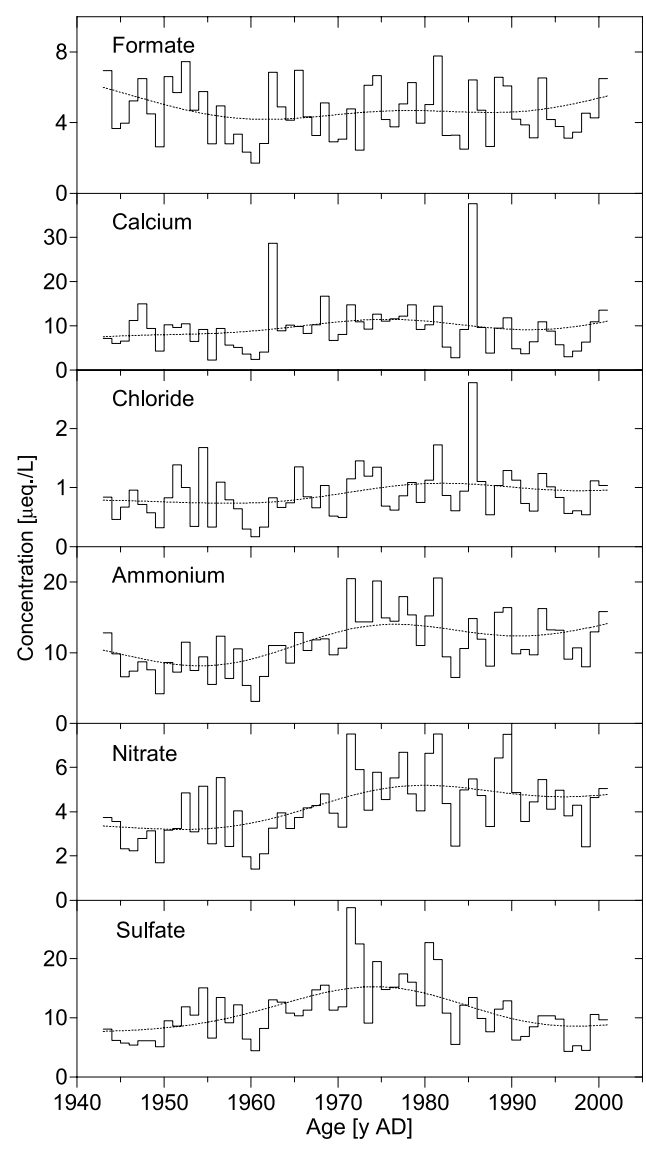

Figure 4. Concentration records of sulphate, nitrate, ammonium, chloride, calcium and formate (annual averages). Dashed curves represent smoothed values to guide the eye.

sodium (not shown) these values fail to show a discernable temporal trend. In contrast trends that might be due to anthropogenic activity in the former Soviet Union are observed for sulfate, nitrate, chloride and ammonium. These are not due to changes in the accumulation rate since in this case all species would have been affected similarily.

[22] Terrestrial dust has been postulated as the main source of sulfate and nitrate in Tien Shan snow [Wake et al., 1990; Williams et al., 1992; Sun et al., 1998; Kreutz et al., 2001]. The differing temporal trends observed for sulfate, nitrate and calcium suggest that dust is not the only source of those two anions in the Belukha region. Anthropogenic sulfate was observed in snow from northwest China [Wake et al., 1992] and in snow throughout the former Soviet Union [Belikova et al., 1984]. The maximum (about 1975) observed in the sulfate record from Belukha suggests that at least part of the sulfate originates from $\mathrm{SO}_{2}$ emissions. Annual nitrate averages show an increasing trend from 1965 to 1975 which is likely due to the growth of traffic and the associated rise of the emission of precursor gases $\mathrm{NO}_{\mathrm{x}}$.

[23] The ammonium signal recorded in the Altai ice core is primarily attributed to biogenic emissions, biomass burning and anthropogenic emissions related to agricultural activities (e.g. livestock and the use of nitrogen-rich fertilizer). 
[24] In conclusion, the glaciochemical data presented here indicate that the Belukha glacier provides a probably unique archive of atmospheric and environmental conditions in central Asia.

[25] Acknowledgments. We would like to thank: Andrea Bosshard and Walter Fetscherin, Swiss Ambassador in Russia, for their support, Nestlé, Russia, for sponsoring aliments for the expedition, Altaikholod Ltd,, Barnaul, for access to their cold room, Siberia Airline for shipping the ice, Patrick Ginot and Beat Rufibach for drilling, Henrik Rhyn, Dimitrii N. Kozlov, Sergej Derewstschikow, Vladimir Vashenzev and Andrej Jerjomin for their help during the expedition, Christoph Kull for providing the AWS, Veronica Morozova for preparing the customs documents for ice and equipment shipping and the helicopter pilots Alexander Chebotkin and Igor Karakulko.

\section{References}

Belikova, T. V., V. N. Vasilenko, I. M. Nazarov, A. N. Pegoev, and S. D. Fridman, Characteristics of background sulfate pollution of the snow cover on the territory of the USSR, Meteorologiya $i$ Gidrologiya, 9, $47-55,1984$.

Döscher, A., H. W. Gäggeler, U. Schotterer, and M. Schwikowski, A historical record of ammonium concentrations from a glacier in the Alps, Geophys. Res. Lett., 23(20), 2741-2744, 1996.

Eichler, A., Deposition von Spurenstoffen in Firn und Eis alpiner Gletscher, Untersuchung von Nord-Süd-Gradienten, Ph.D. thesis, Univ. ät Bern, Bern, 2000.

Gäggeler, H. W., H. R. Von Gunten, E. Rössler, H. Oeschger, and U. Schotterer, ${ }^{210} \mathrm{~Pb}$-dating of cold alpine firn/ice cores from Colle Gnifetti, Switzerland, J. Glaciol., 29(101), 165-177, 1983.

Gao, Y., R. Arimoto, M. Y. Zhou, J. T. Merrill, and R. A. Duce, Relationships between the dust concentrations over eastern Asia and the remote north Pacific, J. Geophys. Res., 97(D9), 9867-9872, 1992.

Ginot, P., F. Stampfli, D. Stampfli, M. Schwikowski, and H. W. Gäggeler, FELICS, a new ice core drilling system for high-altitude glaciers, Proc. of the workshop "Ice Drilling Technology 2000", Mem. Natl. Inst. Pol. Res., Spec. Issue, 38-48, 2002.

ISO, International Organization for Standardization, Geneva, Guide to the expression of uncertainty in measurement, corrected and reprinted 1995.

Keene, W. C., A. A. P. Pszenny, J. N. Galloway, and M. E. Hawley, Sea-salt corrections and interpretation of constituent ratios in marine precipitation, J. Geophys. Res., 91(D6), 6647-6658, 1986.

Kreutz, K. J., V. B. Aizen, L. D. Cecil, and C. P. Wake, Oxygen isotopic and soluble ionic composition of a shallow firn core, Inilchek glacier, central Tien Shan, J. Glaciol., 47(159), 548-554, 2001.

Lavanchy, V. M. H., H. W. Gäggeler, U. Schotterer, M. Schwikowski, and U. Baltensperger, Historical record of carbonaceous particle concentrations from a European high-alpine glacier (Colle Gnifetti, Switzerland), J. Geophys. Res., 104(D17), 21,227-21,236, 1999.

Liu, T. S., X. F. Gu, Z. S. An, and Y. X. Fan, The dust fall in Beijing, China on April 18, 1980, Geological Soc. Of America (Special Paper 186), 149-157, 1981.

Lüthi, M. P., and M. Funk, Modelling heat flow in a cold, high-altitude glacier: Interpretation of measurements from Colle Gnifetti, Swiss Alps, J. Glaciol., 47(157), 314-324, 2001.

Parrington, J. R., W. H. Zoller, and N. K. Aras, Asian dust: Seasonal transport to the Hawaiian Islands, Science, 220, 195-197, 1983.
Preunkert, S., M. Legrand, and D. Wagenbach, Sulfate trends in a Col du Dome (French Alps) ice core: A record of anthropogenic sulfate levels in the European midtroposphere over the twentieth century, J. Geophys. Res., 106(D23), 31,991-32,004, 2001.

Rosman, K. J. R., C. Ly, K. Van de Velde, and C. F. Boutron, A two century record of lead isotopes in high altitude Alpine snow and ice, Earth. Planet. Sci. Lett., 176(3-4), 413-424, 2000.

Schotterer, U., P. Schwarz, and V. Rajner, From pre-bomb levels to industrial times: A complete tritium record from an alpine ice core and its relevance for environmental studies, International symposium on isotope techniques in the study of past and current environmental changes in the hydrosphere and the atmosphere, 581-590, Vienna, 1998.

Schwikowski, M., S. Brütsch, H. W. Gäggeler, and U. Schotterer, A highresolution air chemistry record from an Alpine ice core: Fiescherhorn glacier, Swiss Alps, J. Geophys. Res., 104(D11), 13,709-13,719, 1999a. Schwikowski, M., A. Döscher, H. W. Gäggeler, and U. Schotterer, Anthropogenic versus natural sources of atmospheric sulphate from an Alpine ice core, Tellus, 51B, 938-951, 1999b.

Shugui, H., Q. Dahe, Z. Dongqi, K. Shichang, P. A. Mayewski, and C. P. Wake, A 154a high-resolution ammonium record from the Rongbuk Glacier, north slope of Mt. Qomolangma (Everest), Tibet-Himal region, Atmos. Environ., 37, 721-729, 2003.

Shumskii, P. A., Principles of structural glaciology (transl. D. Kraus), 497 pp., Dover Publications Inc., New York, 1964.

Sun, J., and others, Soluble species in aerosols and snow, and their relationship at Glacier 1, Tien Shan, China, J. Geophys. Res., 103(D21), 28,02128,028, 1998.

Tarussov, A., The Arctic from Svalbard to Severnaya Zemlya: Climatic reconstructions from ice cores, in Climate Since A.D. 1500, edited by R. S. Bradley and P. D. Jones, 505-516, Routledge, New York, 1992.

Van de Velde, K., C. Barbante, G. Cozzi, I. Moret, T. Bellomi, C. Ferrari, and C. Boutron, Changes in the occurrence of silver, gold, platinum, palladium and rhodium in Mont Blanc ice and snow since the 18th century, Atmos. Environ., 34(19), 3117-3127, 2000.

Wagenbach, D., Environmental Records in Alpine Glaciers, in The Environmental Record in Glaciers and Ice Sheets, edited by H. Oeschger and C. C. Langway Jr., 69-83, John Wiley \& Sons Limited, 1989.

Wake, C. P., P. A. Mayewski, and M. J. Spencer, A review of central Asian glaciochemical data, Ann. Glaciol., 16, 301-306, 1990.

Wake, C. P., P. A. Mayewski, W. Ping, Y. Qinzhao, H. Jiankan, and $\mathrm{X}$. Zichu, Anthropogenic sulfate and Asian dust signals in snow from Tien Shan, northwest China, Ann. Glaciol., 16, 45-52, 1992.

Wake, C. P., P. A. Mayewski, X. Zichu, W. Ping, and L. Zhongqin, Regional distribution of monsoon and desert dust signals recorded in Asian glaciers, Geophys. Res. Lett., 20(14), 1411-1414, 1993.

Williams, M. W., K. A. Tonnessen, J. M. Melack, and Y. Daqing, Sources and spatial variations of the chemical composition of snow in the Tien Shan, China, Ann. Glaciol., 16, 25-32, 1992.

S. Olivier, H. W. Gäggeler, U. Schotterer, and E. Vogel, Department of Chemistry and Biochemistry, University of Bern, Bern, Switzerland.

M. Schwikowski, S. Brütsch, M. Saurer, and L. Tobler, Paul Scherrer Institute, Villigen, Switzerland. (margit.schwikowski@psi.ch)

M. Lüthi, Versuchsanstalt für Wasserbau, Hydrologie und Glaziologie, ETH Zürich, Zürich, Switzerland.

S. Eyrikh and T. Papina, Institute for Water and Environmental Problems, Siberian Branch of the Russian Academy of Sciences, Barnaul, Russia. 